\title{
GYEREKKORBAN KREATÍV CSOPORTMUNKA, FELNÖTTKORBAN VERSENYELŐNY?! A közép-dunántúli régióban megvalósított akciókutatás eredményének bemutatása
}

\author{
CREATIVE TEAMWORK IN CHILDHOOD, \\ COMPETITIVE ADVANTAGE IN ADULTHOOD?! \\ Presentation of the Results \\ of an Action Research in the Central Transdanubian Region
}

\author{
Horváth Daniella Dominika' ${ }^{1}$, Bereczky Réka ${ }^{2}$ \\ ${ }^{1}$ PhD-hallgató, Budapesti Corvinus Egyetem, Budapest \\ daniella.horvath@uni-corvinus.hu \\ ${ }^{2}$ BA-hallgató, Budapesti Corvinus Egyetem, Budapest \\ reka.bereczky@stud.uni-corvinus.hu
}

\section{ÖSSZEFOGLALÁS}

Tanulmányunk célkitǔzése az általános iskolában alkalmazott, a kreativitás fejlesztésére irányuló, a designkommunikáció módszertanára építő csoportmunka lehetséges vállalati aspektusainak vizsgálata egy közép-dunántúli régióban megvalósított akciókutatás fókuszba állításán keresztül. Kutatásunk során törekedtünk a tudományterületek közötti kommunikáció és kapcsolódás erősítésére a design, az oktatás és az üzleti kommunikáció területei között, akciókutatásunk központi elemét a meglévő szinergiák összhangjára építettük. Szakirodalmi összegzésünk vizsgálja az iskolai csoportmunka vállalati aspektusait, megnéztük, hogy melyek azok a legfontosabb készségek, melyeket a munkavállaló elvár, és ezen készségek hogyan fejleszthetők a csoportmunkán keresztül. Középpontba kerül az együttműködés jelentősége, tanulható jellege. Irodalomfeldolgozásunk záró szakaszát a kooperáció, a csapatmunka iskolai alkalmazásának lehetőségei alkotják. A tanulmányban bemutatjuk saját fejlesztésű módszertanunk tervezői megközelítésének a szakirodalmi elemzéssel összehangzó és elvárt oktatási és vállalati hozadékait. Bemutatásra kerül a közép-dunántúli régió három településén megvalósított akciókutatás, melynek során a gyerekek által írt reflexiók és a pedagógus mélyinterjúk kódolása révén arra a kérdésre keressük a választ, hogy a designkommunikáció workshop hogyan járulhat hozzá a csoportmunka, a közös gondolkodás és alkotás fejlesztéséhez, valamint milyen hatást gyakorol a diákok együttműködésére? Kutatásunkban továbbá arra kerestük a választ, hogy az általános iskolai keretek között alkalmazott rendszeres csoportmunka hogyan járulhat hozzá olyan készségek fejlesztéséhez, melyek a munkavállalói piacon versenyelőnyt jelentenek majd a diákok számára. Összegzésünk során megfogalmazzuk a kutatás következtetéseit, összegezzük elméleti és gyakorlati hozzáadott értékét, valamint megfogalmazzuk a jövőbeni kutatási irányokat. 


\section{ABSTRACT}

The aim of our study is to examine the possible corporate aspects of teamwork applied in elementary schools, based on the methodology of design communication, by focusing on action research in the Central Transdanubian region. In our research we have sought to strengthen communication and connectivity among disciplines between design, education, and business communication. We built the core of our action research on the consistency of existing synergies. Our literature review examines the corporate aspects of school teamwork. We looked at the key skills that an employee expects and how these skills can be developed through teamwork. The significance and the learnable nature of the cooperation are in focus. The final phase of our literature review is the opportunities for collaboration and teamwork at school. In this paper, we present the educational and business benefits of a design approach from our proprietary methodology that aligns with and expects literature analysis. In the second half of our analysis, action research on three settlements in the Central Transdanubian region will be presented.

As a result of reflection written by children and coding of teacher in-depth interviews, we seek to determine how the design communication workshop can contribute to the development of teamwork, collaborative thinking, and creativity, and positively impact collaboration. In addition, our research seeks to determine how regular teamwork within primary schools can help develop skills that will provide students competitive advantages in the labour market.

In the summary, we formulate the conclusions of the research, summarize the theoretical and practical added value of our research, and outline future research directions.

Kulcsszavak: oktatás, csoportmunka, designkommunikáció, együttműködés, akciókutatás

Keywords: education, teamwork, designcommunication, co-operation, action research

\section{BEVEZETÉS}

A vállalatok sikeres müködésének egyik alappillére az együttmüködő képesség, amelynek eredményeképpen a vállalkozók számára kiemelkedő fontosságúvá vált ez a tulajdonság a legújabb munkatársak alkalmazásakor. Így azok a frissen végzett hallgatók, akik ezen képesség birtokában vannak, nagyobb elönnyel lépnek ki a munkavállalók világába. Mivel az együttműködő képesség tanulható és fejleszthető, fontos, hogy oktatásuk során megfelelő tapasztalatot szerezzenek ezen a téren, és az is fontos, hogy ezt minél fiatalabb korban kezdjék. ,...mind az általános iskolákban, mind pedig a középfokú oktatásban is a tanári magyarázat és a frontális osztálymunka vezet az oktatás során a tanárok által alkalmazott módszerekben. A középiskolai korosztálynak megfelelően a középiskolákban nagyobb az önálló tanulói munka szerepe. A csoportmunka és pármunka viszont aránytalanul kevesebbszer jelenik meg a középiskolai tanári gyakorlatban.” (Radnóti, 2006, 131.) Bár az elmúlt időszakban egyre többen alkalmaznak 
alternatív módszereket az oktatásban, a kooperációra alapuló munka továbbra is elhanyagolható arányban van jelen az oktatásban (Szücs, 2018). Tanulmányunkban először az iskolai csoportmunka vállalati aspektusait tárgyaljuk, majd az együttműködő-képesség fejleszthetőségét és az általános iskolákban jelen lévő csoportmunkát vesszük górcső alá. Ezt követi a designkommunikáció módszertanának bemutatása, mely tervezői megközelítésére építettük a tanulmány második felében ismertetésre kerülő saját fejlesztésü workshopot. Továbbá itt kap helyet a közép-dunántúli régióban megvalósuló akciókutatásunk elemzése, melynek során a következő kutatási kérdésekre keressük a választ: A designkommunikáció workshop hogyan járulhat hozzá a csoportmunka, a közös gondolkodás és alkotás fejlesztéséhez (KK1). Szeretnénk továbbá választ kapni, hogy a designkommunikáció milyen hatást gyakorol a diákok együttmüködésére (KK2). Továbbá kutatási kérdésként fogalmaztuk meg, hogy az általános iskolai keretek között alkalmazott rendszeres csoportmunka hogyan járulhat hozzá olyan készségek fejlesztéséhez, melyek a munkavállalói piacon versenyelönyt jelentenek majd a diákok számára (KK3).

\section{SZAKIRODALMI ÖSSZEFOGLALÓ}

\section{Az iskolai csoportmunka vállalati aspektusai}

Az elmúlt évtizedek tapasztalatai azt mutatják, hogy a vállalati szférában egyre értékesebbé válik a munkavállalók elköteleződése az adott vállalat irányába, ez pedig akkor tud megvalósulni, ha megfelelö a kommunikáció, az együttmüködésre való készség, illetve adott a fejlődésre való lehetőség és megfelelő a jutalmazási rendszer (Ramdhani et al., 2017). Az együttmüködés fogalma pedig ezek közül is kiemelkedő fontosságú a vállalati kultúrában, hiszen nemcsak az elköteleződést segíti, hanem a hatékonyságot is növeli. Elég csak a projektmenedzsmentre, az irodai megbeszélésekre, cégek közötti partnerkapcsolatokra vagy az igazgatótanácsokra gondolni a privát és az állami szektorban is, mind arra mutatnak, hogy az együttmüködő képesség nélkülözhetetlen. Ha a munkaerö-termelésre mint folyamatra tekintünk, akkor az oktatás eredménye vagy „outputja” a vállalati közeg ,inputja” lesz. Egy 2018-ban végzett National Association of Colleges and Employers (USA) felmérés során 172 vállalat vezetőjét kérték meg, hogy sorolják fel azokat a készségeket/tulajdonságokat, amelyeket a legfontosabbnak tartanak egy potenciális, frissen végzett munkavállalóval szemben. A felmérésben olyan nagyvállalatok vezetői vettek részt, mint a GE Appliances vagy a National Instruments. Ez alapján az együttmüködés harmadik lett a listán, ezt csak a kommunikációs képesség és a problémamegoldó képesség előzte meg (NACE, 2018). 


\section{Az együttmúködés mint tanulható készség}

Felsőoktatási keretek között már érződik - főként az orvostudományi és gazdálkodástudományi egyetemek esetében -, hogy a fenti tényeket figyelembe véve, különböző módszerek alkalmazásával serkentik ezen kulcsfontosságú készségek elsajátítását. Ismeretes, hogy egyes egyetemek például teljesen átálltak a problémaalapú tanításra - amely során kis csoportokban, együttes erővel keresik a megoldást az adott problémára - éppen azért, hogy a végzett hallgatók ezáltal is nagyobb előnnyel lépjenek ki a munka világába (Cohen-Schotanus et. al., 2008). Az együttműködés pedig igenis tanulható készség, ezt bizonyítja Saundra J. Reinke 2001-es kutatása is, amelyből kiderül, hogy az olyan kollaboratív metódusok alkalmazása, amelyek a csoportmunkán alapszanak, már rövid időn belül is képesek fejleszteni az együttmüködő képességet, és ráadásul nemcsak a diák-diák, de a diák-tanár kapcsolatokat is képesek megerősíteni (Reinke, 2001). Mindezeket figyelembe véve nemcsak a felsőoktatásban, de már egészen kicsi korban is kritikus jelentőséggel bír az együttmüködésre tanító foglalkozások jelenléte, illetve az ezekhez szükséges környezet megléte.

\section{Csoportmunka az általános iskolában}

A darwinizmus felemelkedésével egyidős a vélekedés, hogy a túlélésért bizony küzdeni kell, és csak a legerősebb éli túl a kihívásokat. Az együttmüködésen alapuló nézet azonban elutasítja ezt, és azt álltja, hogy az emberiség a kooperációnak köszönheti az elért fejlettségi szintet (Apicella-Silk, 2019). Régen valakivel együtt tanulni azt jelentette, hogy az illető nem képes mások segítsége nélkül „felkészülni", ma azonban ez az egyik legjobb stratégia a tanulás tanulására (Chen, 2002). A legtöbb magyar fiatal jobban ismeri a versenyszellem fogalmát, mint a csapatszellemét, hiszen egymással versenyeznek a jobb jegyekért, bejutásért a legjobb gimnáziumokba. Bizonyított azonban, hogy az oktatás során alkalmazott csoportmunka megerősíti a közösséget, növeli a munka értékét, segíti a diákokat az új dolgok megértésében és elfogadásában (Robbins, 1994), és egyéb szociális készségeket - kommunikációs készség, konfliktuskezelés - is képes fejleszteni (Altun, 2017). Ezenfelül, a heterogén csoportok kialakítása lehetővé teszi, hogy a diákok egymást motiválják (Szücs, 2018). Bár ezen tények mindenki számára ismertek, mégis kevés tanár él az órákon megvalósítható csoportmunka lehetőségével, hiszen nemcsak időigényes, de fennáll a társas lógás lehetősége is, illetve a tantervben szereplő tananyag mennyisége és az idő hiánya is korlátozza őket. Ez még inkább igaz az általános iskolákra, ahol közismerten feszített tempóval haladnak a tananyaggal. Azonban be kell látnunk, hogy igenis fontos megtanítani már az általános iskolás diákoknak is, hogy hogyan tudnak együttmüködni, ezen képesség hiánya ugyanis gyenge teljesítményhez is vezethet (Vargas et al., 2018). 
A legtöbben ennek fényében is csak leginkább felső tagozaton kezdenek megismerkedni ezzel a tanulási módszerrel.

\section{MÓDSZERTAN}

\section{A designkommunikáció workshop}

A designkommunikáció módszertana a későbbiekben is roppant hasznos, a csapatmunkában rejlő lehetőséget próbálja kiaknázni tanulók körében. A designkommunikáció fejlesztésbe (fejlődésbe) integrált kommunikációt jelent (Cosovan, 2009), amely képes hidat teremteni különböző nézetek, társadalmi és gazdasági jelenségek között (Horváth D. D., 2018). A módszer alkalmazásának egyik indítéka, hogy kapcsolatot teremtsünk az együttmüködésen keresztül az oktatás és a vállalati közeg között (Cosovan-Horváth, 2016). A módszertan segítségével egy olyan nyílt probléma megoldására vállalkoznak a diákok, amelyről csak annyit tudnak, hogy az objektív jó irányába haladhatnak, egy olyan jó megoldás felé, amely nekik is jó és másnak is jó. Cél, hogy ne szabjunk határt a kreativitásnak, és hogy a gyerekeknek olyan környezetet biztosítsunk, ahol bátran fel merik vállalni a véleményüket, hiszen nincs rossz kérdés vagy rossz válasz, és mindenki egyenlő, mindenki hozzászólása egyaránt értékes. A problémaalapú megközelítés, a kritikai, tervezöi szemlélet és az együttmüködés, a közös „,együttalkotás”, a fejlődésbe integrált kommunikáció alkotják a módszertan alappilléreit, mely kifejezetten azon képességek fejlesztésére fókuszál, melyek nagymértékben öszszecsengést mutatnak a 2018-ban készített felmérés eredményeivel, ami a munkavállalók elvárásait rangsorolta (NACE, 2018). A következő fejezetben szeretnénk megmutatni az olvasónak, hogy a módszertan milyen, a gyakorlatban is megvalósított és kutatott eszközökkel próbálja összehangolni az oktatás „outputját” a vállalat ,inputjával”.

\section{Az akciókutatás gyakorlati megvalósitása}

A designkommunikáció módszertanára építve egy saját fejlesztésủ foglalkozást hoztunk létre, melynek elsődleges célcsoportját az általános iskolák felső tagozatos diákjai és tanáraik alkotják, de másodlagos célcsoportként tartjuk számon az alapfokú oktatás minden szereplöjét. A foglalkozás kiindulópontja, hogy egy valós, hétköznapi, a részt vevő gyerekek számára ismert kérdéskör, az otthon jobbá tétele köré szerveződik a hozzávetőlegesen 150 perc hosszúságú workshop. Első lépésként a designkommunikáció módszertanának lényegi elemeit ismertetjük a részt vevő diákokkal prezentáció formájában. Ezt követően véletlenszerüen kialakított négy-öt fös csoportokban, majd a tömeges együttműködés eszköztárát 
alkalmazva, osztályszinten valósul meg az együttmüködés, a tervezői folyamat, a problémát lehetőséggé formáló szemléletben az aktív, cselekvő, közös alkotás.

Jelen tanulmányban a közép-dunántúli régió három megyéjében (Fejér, Komárom-Esztergom és Veszprém megye) megvalósított akciókutatás eredményét mutatjuk be, a létrehozott produktum, a diákok által írt reflexiók és az akciókutatás eredményeinek összegzésével.

Kutatási kérdésünk során arra keressük a választ, hogy a designkommunikáció workshop hogyan járulhat hozzá a csoportmunka, a közös gondolkodás és alkotás fejlesztéséhez (KK1). Szeretnénk továbbá választ kapni, hogy a designkommunikáció milyen hatást gyakorol a diákok együttműködésére (KK2). Továbbá kutatási kérdésként fogalmaztuk meg, hogy az általános iskolai keretek között alkalmazott rendszeres csoportmunka hogyan járulhat hozzá olyan készségek fejlesztéséhez, amelyek a munkavállalói piacon versenyelőnyt jelentenek majd a diákok számára (KK3). A vizsgált kutatási kérdés természetéhez igazodik a kvalitatív megközelítés, mely lehetővé teszi, hogy a miértekre, a mélyebb összefüggésekre fókuszálhassunk elemzésünkben (Horváth-Mitev, 2015). Az akciókutatás során a vizsgálat fókuszát a hatodik osztályos diákok és osztályfőnökeik jelentették, mindhárom iskolában osztályszinten tartottuk meg a foglalkozást. Az iskolák a Nemzeti Alaptantervet követő, normál tanrendủ általános iskolák. A diákok által írt reflexiók és a pedagógusokkal készített szakértői mélyinterjúk elemzését követően kialakítottunk négy dimenziót, melyek mentén elöször megyénként ismertetjük a kutatás eredményeit, majd összegezzük a feltételezett szinergiákat az egyes helyszínek között, a szakirodalmi elemzés során megfogalmazott ismeretek tükrében. A kódolás az Anselm Strauss és Juliet Corbin (1994) által képviselt iránymutatások szerint zajlott. A nyílt kódolási folyamatot az axiális kódolás, a kategóriák összevonása, majd a kulcskategóriákra redukálás jellemezte. Így alakult ki az a négy fő dimenzió, melyek mentén elemzésünk megvalósul: (1) szubjektiv értékitélet, (2) csapatmunka, (3) alkotói kapcsolatteremtés, (4) osztályközösség. Az idézetek azonosíthatósága érdekében a diákokat a helyszín és egy sorszám segítségével kódoltuk, így biztosítva az anonimitást, a személyiségi jogok tiszteletben tartását.

\section{KUTATÁSI EREDMÉNYEK}

\section{Az eredmények ismertetése}

Tapolcán, Veszprém megyében a kutatás helyszínét a Bárdos Lajos Általános Iskola Kazinczy Ferenc Tagintézménye biztosította, a foglalkozás 2019. szeptember 17-én valósult meg, huszonkét diák részvételével. A gyerekek kivétel nélkül nagyon jól érezték magukat a foglalkozáson, (1) élményt jelentett számukra, és 
azt is kifejezték, hogy szeretnék, ha ez megismétlődne: „nagyon jól éreztem magam, szuper jó volt ez a mai nap” - Tapolca 29, „,nagyon tetszett a sok öröm, amit az arcokon láttam” - Tapolca 23, „remélem máskor is lesz ilyen, mert akkor már nagyon-nagyon várom/várnám" - Tapolca 24. A csoportmunka tekintetében (2) sikerült egy közös produktumot létrehozni, mely egy önellátó, megújuló energiákkal múködő farmot jelentett. Egyértelmüen látszott a közösségen, hogy nem először dolgoznak csoportban, melyet a pedagógussal készített interjú is alátámasztott. Az interjú arra is rávilágít, hogy minél kisebb korban kezdődik el a csoportmunka iskolai keretek között, annál hatékonyabbá válik az együttmüködés az évek előrehaladtával: „Az én véleményem: Igazi csoportmunkát alsó tagozattól lehetne építeni. Tehát ha ott kialakítják a gyerekekkel a csoportban való együtt dolgozás lehetőségét, ha megszokja a gyerek, akkor sokkal könnyebb velük a későbbiek során így dolgozni" - Tapolca-osztályfőnök, ez összhangban van a szakirodalmi elemzéssel (Vargas et al., 2018), továbbá kutatási kérdésünk igazolását is segíti (KK3). Fontos a csoportmunka kapcsán még kiemelni, hogy a gyerekek nagyon szeretik, a reflexiókban igen fontos szerep jutott ennek kifejezésére: „A legjobban az tetszett, amikor csoportokba kellett dolgozni” - Tapolca 42. A közös alkotás, az alkotói kapcsolatteremtés (3) dimenziója ezen a helyszínen kiemelten jelen volt (KK1). Felismerték a jelentőségét, sikerélményként könyvelték el, hogy milyen jól dolgoztak együtt osztályként: „Nagyon jól dolgoztunk együtt, mert megoldottuk a feladatot" - Tapolca 39, ugyanakkor hiányosságaikkal és a fejlödés lehetőségének és szükségességének fontosságával is tisztában vannak: „Nagyrészt sikerült együtt dolgoznunk, de idővel mehet majd még jobban is" - Tapolca 38. Szorosan kapcsolódik az együttmüködéshez az osztályközösség (4) (Robbins, 1994). Tapolcán a vizsgált közösség osztályfönöke az iskolai kereteken kívül is számtalan közösségépítő kirándulást, programot szervez, azonban még így is vannak széthúzások az osztályban, mely a feladat megoldása során is érezhetően megjelent. A hiányosságot a gyerekek is felismerik: „amúgy nem lenne rossz az osztályközösség, csak pár ember elhülyéskedi” - Tapolca 30. Ugyanakkor a jó osztályközösségre való törekvés a tanulmányi eredmények javítása okán sem elhanyagolható: „Ha jó egy közösség, ha meghallgatják egymást, ha segítik egymást, akkor ez a tanulmányi munkában is eredményekhez vezethet" - Tapolca-osztályfőnök (KK2).

A Fejér megyei településen, Baracson a Széchenyi Zsigmond Általános Iskola és Alapfokú Mủvészeti Iskola intézetében került sor a kutatásra 2019. november 19-én, huszonöt diák részvételével. Az osztályra összességében jellemző volt, hogy a véleményük kifejezése akadozik, ez mind szóban, mind írásban a reflexiók hosszán és a használt kifejezésmódban is megmutatkozott, egyszerủen, röviden, nem választékosan fogalmaztak. A szubjektív megítélésük (1) a workshopról, az élmény, amit kaptak, kétségkívül pozitív: ,jól éreztem magam, szerintem jó volt ez a két óra" - Baracs 73. A csoportmunka (2) egyáltalán nem jellemző az 
iskolai keretek között, ez látszott is a diákok viselkedésén, nem hallgatták meg egymást, sokszor vágtak egymás szavába, ami nehezítette a közös produktum megvalósítását, mely végül egy szemétszedéssel összekapcsolt karácsonyi vásár ötleteként realizálódott, de a pontos kidolgozása elmaradt (KK3). Ennek ellenére maga a csoportmunka pozitív érzést keltett a diákokban: „tetszett az, amikor csapatban dolgoztunk" - Baracs 62. Pontosan a fentiekböl adódóan a közös alkotás, az alkotói kapcsolatteremtés dimenziója (3) ezen a foglalkozáson minimálisan volt jelen. Annyiban volt tetten érhető, hogy kiemelték a közös beszélgetés pozitívumait és a jó közösséget, melyben dolgoztak, mely a fent említett irodalomra is visszautal (Vargas et al., 2018). Némileg ellentmondásba ütköztünk az osztályközösség (4) vizsgálata során, hiszen a pedagógus elmondása alapján egy viszonylag jó közösségről van szó, mely közösség erősítése az iskolai kereteken túli programok segítségével is zajlik, azonban az osztályközösségben rejlő ,alkotói közösség”, a „közös tudásalkotás” nem tud felszínre törni. A közép-dunántúli régión kívül megvalósított, összesen huszonnégy workshop eredményei alapján ennek okát két jelenségre vezetjük vissza: egyrészt, a csoportmunka teljes hiánya (feltehetőleg ez a workshop mint közösségi munka az első alkalmak egyike volt számukra, így érthető az alulteljesítés ebben az ismeretlen szituációban, ráadásul idegen facilitátorokkal), másrészt az, hogy a legtöbb tantárgyat csoportbontásban tanulják, így a napjuk nagy részét nem közösségként töltik, feltételezhetően nincs annyi közös élmény, tapasztalás, ismeretük egymással szemben felületes és hiányos lehet (KK1).

A Komárom-Esztergom megyei Dorog településen 2019. november 22-én tartottuk meg a foglalkozást, nagyon közel a baracsi workshop időpontjához, a Dorogi Magyar-Angol Két Tanítási Nyelvü és Sportiskolai Általános Iskolában, tizennyolc diák részvételével. Az, hogy a gyerekeknek a tervezői kapcsolatteremtésre, a designkommunikáció módszertanára építő workshop pozitív élményt nyújt, (1) a dorogi helyszínen is bebizonyosodott: „ma nagyon jó volt és szuper jó volt" - Dorog 57. A csapatmunka minden érintett települést beszámítva egyértelmüen itt volt a legerősebb, pedig az osztályfőnökkel készített interjú alapján van, de nem annyira gyakori a csoportmunka. Véleménye párhuzamba állítható a tapolcai osztályfőnök által elmondottakkal, miszerint „ha nem hozzák már alsóból magukkal, akkor felsőben már rettenetesen nehéz” kialakítani a hatékony csoportmunkához szükséges készségeket (KK3). Az is magyarázatként szolgálhat, hogy jelen projekt során miért lehetett ennyire sikeres az együttmüködés, hogy beigazolódott az osztályfőnök gondolata: „De lehet, ha olyan feladatot kapnak, ami a mindennapi élethez kapcsolódik, ott mást mutat majd." (KK2) A produktum, amit létrehoztak, egy teljességgel kidolgozott osztályelnök-választási koncepció, ahol ,az osztályelnök tervezné az osztály közös jövőjét!". A csapatmunkát valóban közösségi munkaként élték meg: „föleg az tetszett, hogy mindenki úgymond gondolkodott, és csapatmunka 
volt" - Dorog 43. A legerősebben azonban az alkotói kapcsolatteremtés (3) és a jelen workshopnál ettől elválaszthatatlan osztályközösség (4) dimenziója nyert teret, melyet a workshop eredményeként tartunk számon: „,szerintem ez volt eddig az évben a legnormálisabban töltött beszélgetés” - Dorog 58, „részese voltam az osztály összetartásában, és talán ez volt a legjobb” - Dorog 59, ,jó volt látni, hogy az osztály együtt dolgozott, sikerült az osztálynak egy közös döntést hoznia” - Dorog 46, ,tetszett még az, hogy az osztály ilyen harmóniába dolgozott" - Dorog 44. Ök saját maguk is felismerik és elismerik, hogy pozitívan hatott a foglalkozás, a kreatív csoportmunka az osztályközösségükre, elindult egy folyamat a felismerésből, melyet ők önszántukból akarnak tovább vinni: „jónak tartom, hogy az osztályunknak, aminek nem mindig jó a közössége, de most tudtunk egy osztályként gondolkodni” - Dorog 45 , „nagyon jó volt, végre lett egy kis osztályközösség" - Dorog 47 (KK2). Ez volna az elsődleges cél, hogy az általunk fejlesztett foglalkozás ily módon aktiválja a cselekvő folyamatokat. Ez részben összecseng, részben pedig az osztályfőnök által is igazolásra kerül, vagyis „Muszáj lenne az, hogy a gyerekek újat találjanak ki, és egy-egy problémát meg tudjanak oldani a saját elképzeléseik szerint [...] fontos, hogy az iskola tényleg használható tudást adjon át, amiből fog tudni kreatívan alkotni, vagy ha nem is kreatívan, de meg tudja oldani a feladatot." (KK3) Ez a készség az, melyre foglalkozásunk kiemelten fókuszál, és amely a munkavállalói létbe kilépve is kiemelten fontos elsajátítható eszközkészlet, mely versenyelőnyt jelenthet a diáknak (Cohen-Schotanus et al., 2008).

\section{5. ÖSSZEGZÉS}

A tanulmány konklúzióját egy összefoglaló ábrán keresztül szeretnénk az olvasóknak vizualizálni (1. ábra).

Az ábrán igyekeztünk összefoglalni a taglalt szakirodalom és a megvalósított elméleti kutatás között feltárt kapcsolatot, így kutatásunk elméleti hozzáadott értékét. A legfontosabb cél, hogy az oktatás pedagógiai erőforrásait és követelményeit hosszú távon sokkal jobban össze kell hangolni a vállalati, gazdasági, piaci elvárásokkal, mely nem csupán a jövő munkavállalóinak jelenthet versenyelőnyt, de a vállalat számára is egy jövedelmező együttmüködés kezdetét biztosíthatja. Az osztályfőnökök által elmondottakból kiindulva a problémamegoldó szemlélet, a csoportmunkán keresztül megvalósuló együttműködés iskolai keretek közötti rendszeres megvalósítását minél kisebb korban, már alsó tagozatban érdemes elkezdeni, hiszen ez pozitívan hozzájárulhat többek között a munkaerőpiacon is fontosnak vélt készségek (lásd az ábrán) elsajátításához, mely erre vonatkozó kutatási kérdésünkre is válaszként szolgálhat (KK3). Az általunk bemutatott workshop az empirikus kutatás során tapasztalt, kódolt és 


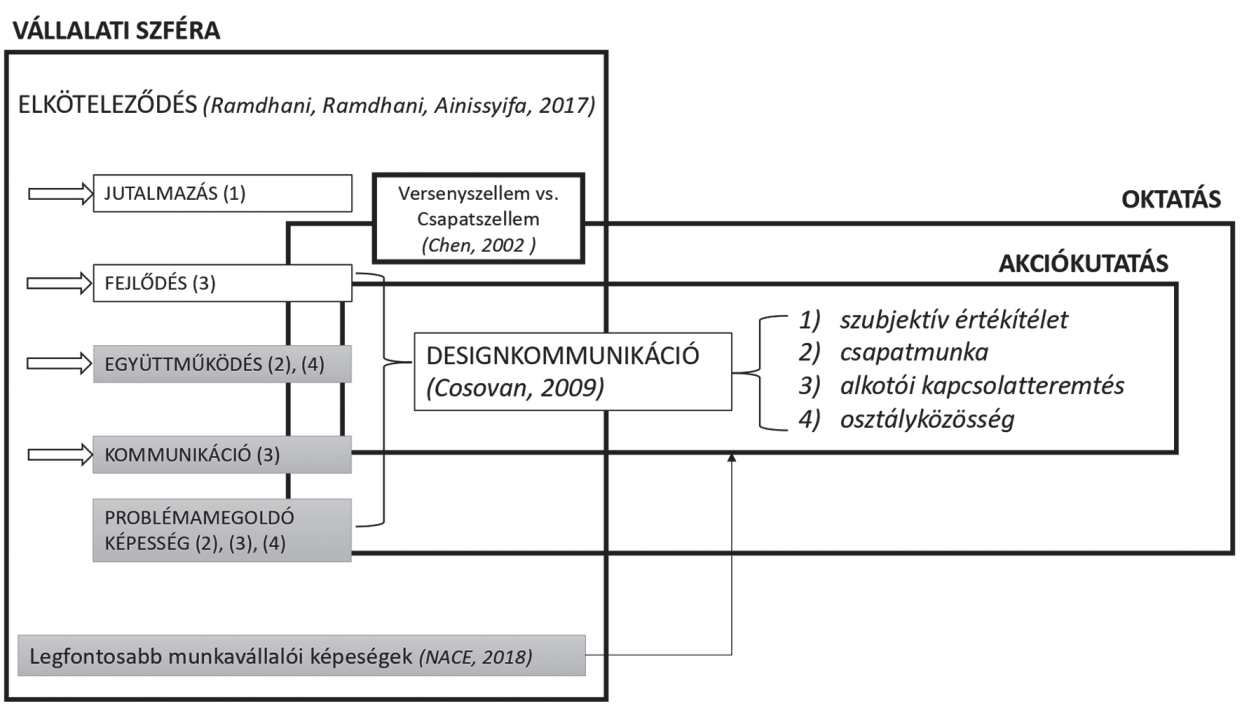

1. ábra. A vállalati szférát és az oktatást összekötő híd feltételezett pillérei a kutatás eredményei alapján

(Az elméleti összegzés és az akciókutatás eredményei alapján, saját szerkesztés)

elemzett eredmények alapján alkalmas a csoport összehangolt együttmüködésének segítésére, mindezt úgy teszi, hogy a közösség erősödik, a tanulók pedig a készségek fejlesztésén túl, ,jutalom gyanánt” egy jó élmény részeseivé is válnak, mely a második kutatási kérdésünkre reflektál. Ez szubjektív értékítéletük alapján is pozitív és eredményes, és nemcsak a csapat, de az egyéni sikerélmény is feltünik. A designkommunikáció workshop ötvözi magában a szakirodalom alapján a vállalatok számára kiemelt fontosságú készségeket, mint az együttmüködés, a problémamegoldó képesség, a fejlődés, valamint a kommunikáció. Ezt az akciókutatásunk során az egyik meghatározó dimenziót vizsgálva, az alkotói kapcsolatteremtésben érhettük tetten, ezzel megerösítve, hogy a designkommunikáció workshop implikálja, a közös gondolkodást és alkotást az osztály tagjai között (KK1). Elmondható tehát, hogy a designkommunikáció általános iskolásoknak szóló foglalkozása magában hordozza a munkavállalói oldalról elvárt legfontosabb képességek fejlesztésének lehetőségét, mindezt úgy, hogy nem igényel extra anyagi vagy eszköz erőforrást az iskola részéről, és viszonylag rugalmasan integrálható a zárt oktatási rendszerbe. Kutatásunk során kiemelt cél volt a társadalmi hasznosság, a kutatásban részt vett pedagógusok és diákok számára új élmény, új tapasztalat biztosítása a foglalkozáson keresztül. Kutatásunk nem reprezentatív, csupán egy lenyomatot, egy benyomást ad a vizsgált probléma kérdéskörében, az azonban bizonyos, hogy az oktatás ilyen irányú fejlesztésére szükség van, tanulmányunk és a foglalkozás által ehhez a fejlődéshez szeretnénk 
hozzájárulni, a pedagógusok számára egy olyan eszközkészletet kidolgozni és átadni, melynek alkalmazása aktív hozzájárulást eredményez a jövő generációjának szemléletformálásához.

Tanulmányunk a Széchenyi 2020 program EFOP-3.6.1-16-2016-00013 „Intelligens szakosodást szolgáló intézményi fejlesztések a Budapesti Corvinus Egyetem székesfehérvári Campusán" címü Európai Uniós projektje keretében készült.

\section{IRODALOM}

Altun, S. (2017): The Effect of Cooperative Learning on Students' Achievement and Views on the Science and Technology Course. International Electronic Journal of Elementary Education, 7, 3, 451-468. https://files.eric.ed.gov/fulltext/EJ1068065.pdf

Apicella, C. L. - Silk, J. B. (2019): The Evolution of Human Cooperation. Current Biology, 29, 11, R447-R450. https://www.cell.com/current-biology/pdf/S0960-9822(19)30334-3.pdf

Chen, C. S. (2002): Self-Regulated Learning Strategies and Achievement in an Introduction to Information Systems Course. Information Tecnology, Learning and Performance Journal, 20, 1, 11-25. https://www.semanticscholar.org/paper/Self-Regulated-Learning-Strategies-and-Achievement-Chen/d0b297b5bf6e03cbc18e9eb7a8b936f47a2f3227

Cohen-Schotanus, J. - Muijtjens, A. M. M. - Schönrock-Adema, J. et al. (2008): Effects of Conventional and Problem-Based Learning on Clinical and General Competencies and Career Development. Medical Education, 42, 3, 256-265. DOI: 10.1111/j.1365-2923.2007.02959.x, https:// www.researchgate.net/publication/229646910_Effects_of_conventional_and_problem-based_ learning_on_clinical_and_general_competencies_and_career_development

Cosovan A. (2009). DISCO. Budapest: Co\&Co Communication. http://issuu.com/cosovan/docs/ ca_disco_web. Letöltés: 2020.03.31.

Cosovan A. - Horváth D. (2016): Emóció - Ráció: Tervezés - Vezetés: Designkommunikáció. Vezetéstudomány / Budapest Management Review, 47, 3, 36-45. http://unipub.lib.uni-corvinus. $\mathrm{hu} / 2307 /$

Horváth D. D. (2018): Design és oktatás: Egy kreatívan irányított kapcsolatteremtés. In: $M M D C$ terelö - Tanulmányok a marketing-, média- és designkommunikáció területéröl. Budapest: $\mathrm{Bu}-$ dapesti Corvinus Egyetem, 115-120. http://unipub.lib.uni-corvinus.hu/3853/

Horváth D. - Mitev, A. (2015). Alternativ kvalitativ kutatási kézikönyv. Budapest: Alinea Kiadó, https://www.researchgate.net/publication/320736610_Alternativ_kvalitativ_kutatasi_kezikonyv

NACE - National Association of Colleges and Employers (2018): Job Outlook 2019. https://www. odu.edu/content/dam/odu/offices/cmc/docs/nace/2019-nace-job-outlook-survey.pdf. Letöltés: 2020. 03. 29.

Radnóti K. (2006): Milyen oktatási és értékelési módszereket alkalmaznak a pedagógusok a mai magyar iskolában? In: Kerber Z.: Hidak a tantárgyak között. Budapest: Országos Közoktatási Intézet, 131-167. http://members.iif.hu/rad8012/pedagogia/Oktatasi-modszerek.doc

Ramdhani, A. - Ramdhani, M. A. - Ainissyifa, H. (2017): Conceptual Framework of Corporate Culture Influenced on Employees Commitment to Organization. International Business Management, 11, 3, 826-830. https://www.semanticscholar.org/paper/Conceptual-framework-ofcorporate-culture-on-to-Ramdhani-Ramdhani/4334d0333ace187a09d13865aa7a6e6f805e200c 
Reinke, S. J. (2001): Teachable Moments: Teaching Teamwork through Research. Journal of Public Affairs Education, 7, 3, 153-160. DOI: 10.1080/15236803.2001.12023510

Robbins, T. L. (1994): Meaningfulness and Community in the Classroom: The Role of Teamwork in Business Education. Journal of Education for Business, 69, 6, 312-316. DOI: 10.1080/08832323.1994.10117706

Strauss, A. - Corbin, J. (1994): Grounded Theory Methodology: An Overview. In: Denzin, N. K. - Lincoln, Y. S. (eds.): Handbook of Qualitative Research. $17^{\text {th }}$ ed. Thousand Oaks, CA: SAGE, 273-285.

Szücs Z. (2018): Tanítási módszerek fontossága a diákok életében, PAIDEIA, 6, 1, DOI: 10.33034/ PAIDEIA.2018.6.1.215, http://real.mtak.hu/93638/1/215_228_Szucs.pdf

Vargas, D. L. - Bridgeman, A. M. - Schmidt, D. R. et al. (2018): Correlation between Student Collaboration Network Centrality and Academic Performance. Physical Review Physics Education Research. 14, DOI: 10.1103/PhysRevPhysEducRes.14.020112, https://arxiv.org/pdf/1808.00315. pdf 